\title{
Variability in Cynara cardunculus L. Tunisian Populations: Seed Germination under Salt Stress
}

\author{
Soumaya KHALDI*, Mohamed El GAZZAH \\ Laboratoire de Biodiversité, Biotechnologies et Changements Climatiques, Faculté des Sciences de Tunis, Université de Tunis El \\ Manar, El Manar, Tunis \\ *Corresponding author: khaldi.soumaya@yahoo.fr
}

Received December 31, 2012; Revised May 02, 2013; Accepted May 05, 2013

\begin{abstract}
Cynara cardunculus.L exhibits an important adaptability to arid and semi-arid regions where high salinity is frequently present. Aiming to introduce its cultivation in the Mediterranean environment especially in Tunisia, it seemed interesting to study seed germination of eight populations of cardoon in four concentrations of $\mathrm{NaCl}: 0 \mathrm{~g} / \mathrm{L}, 2 \mathrm{~g} / \mathrm{L}, 4 \mathrm{~g} / \mathrm{L}$, and $8 \mathrm{~g} / \mathrm{L}$. Our results showed a good variability in salinity stress resistance among the studied populations. Furthermore, six of them exhibited higher germination percentages in $\mathrm{NaCl}$. Therefore, Cynara cardunculus.L may be utilised as a model plant for the study of salt stress responses and to select lines suitable to the cultivation in arid and semi-arid regions of Tunisia.
\end{abstract}

Keywords: cynara, arid, cultivation, $\mathrm{NaCl}$, salinity

\section{Introduction}

Cynara cardunculus. $\mathrm{L}$ is a robust thistle widespread in arid and semi-arid regions of Tunisia where high salinity is frequently present; the wild taxon [var. sylvestris (Lamk) Fiori] has been recognized as the ancestor of both the globe artichoke [var. scolymus (L.) Fiori, ssp. scolymus (L.) Hegi] and the leafy or cultivated cardoon (var. altilis DC) [1].

The wild cardoon (Cynara cardunculus L. subsp. flavescens Wiklund (syn. C. cardunculus var. sylvestris) is a robust thistle with a rosette of large and spiny leaves and branched flowering stems. It's allogame and propagated by seeds (achenes), although the germination can occur throughout the year during the good conditions, the growth extends from September (emergence) to July (mature achenes), and the flowers are usually produced by plants of two years [2]. This taxon is fully crosscompatible and interfertile with both the globe artichoke and the cultivated cardoon [3].

The cultivated cardoon (Cynara cardunculus var. altilis. DC) is known by its fleshy stems and petioles and it's propagated by seeds, it remains of regional importance in the north of Africa and in Tunisia, where it's used in traditional dishes like the Tunisian "couscous". The edible parts of the plant are the fleshy stems, which are typically collected in late autumn-early winter.

The artichoke (Cynara scolymus L.) is largely cultivated all around the world. In Tunisia, it's cultivated in the northern irrigated areas; this species valorizes efficiently heavy soils and sodium chloride water charged, occurring frequently in the low valley of Medjerda, where this culture is frequently cultivated. The edible parts of this plant are the heads. 'Violet d'Hyéres' and 'Blanc
Oranais' are the two most important cultivars in Tunisia [4].

The globe artichoke is the most economically important taxon of this species, with about 120000 ha cultivated in the World [5], and a vegetative propagation system by rooted offshoots in a dormant or active growing state or by rooted basal stem portions [3].

Cynara cardunculus L. is characterized by its appetite stimulation, liverprotective and blood lipid-lowering effect [6] and it's used in the mediterranean regions as food, as a vegetable and as a substitute for rennet for milk coagulation. The roots contains inulin which is known as an enhancer of the human intestinal flora, while the leaves are a source of antioxidant compounds that possess antibacterial activity [7] and they are particularly known in folklore for their therapeutic potential as diuretic, choleretic, cholagogue and antidiabetic agent [8,9].

Furthermore, mono and dicaffeoylquinic acids which are present in cardoon extracts showed anti-HIV integrase activity [10].

However, the cultivation of Cynara cardunculus requires a good understanding of its germination behaviors in response to several environmental constraints. In arid environments, many uncontrolled factors may influence germination, particularly the presence of salt in soil $[11,12]$. It was recognized that the salinity is a severe and increasing constraint on the productivity of agricultural crops. High concentrations of salt in the soil have a strong inhibitory effect on the growth of all crop species [13].

Different plant species and genotypes within a species respond differently to salt stress at different growth stages [14]. Moreover, the plants could be grouped in four categories, according to the influence of salinity on growth: obligatory halophytes, facultative halophytes, 
slightly-salt tolerant non halophytes and halophobic plants [15].

We conducted this research in the objective to evaluate the effect of different $\mathrm{NaCl}$ concentrations on the germination of different wild cardoon, cultivated cardoon and artichoke populations. $\mathrm{NaCl}$ was used in this study because it constitutes the most abundant salt found in environment affected by salinity.

\section{Material and Methods}

The experiments were conducted using a randomized block design with four replications, including the following factors:

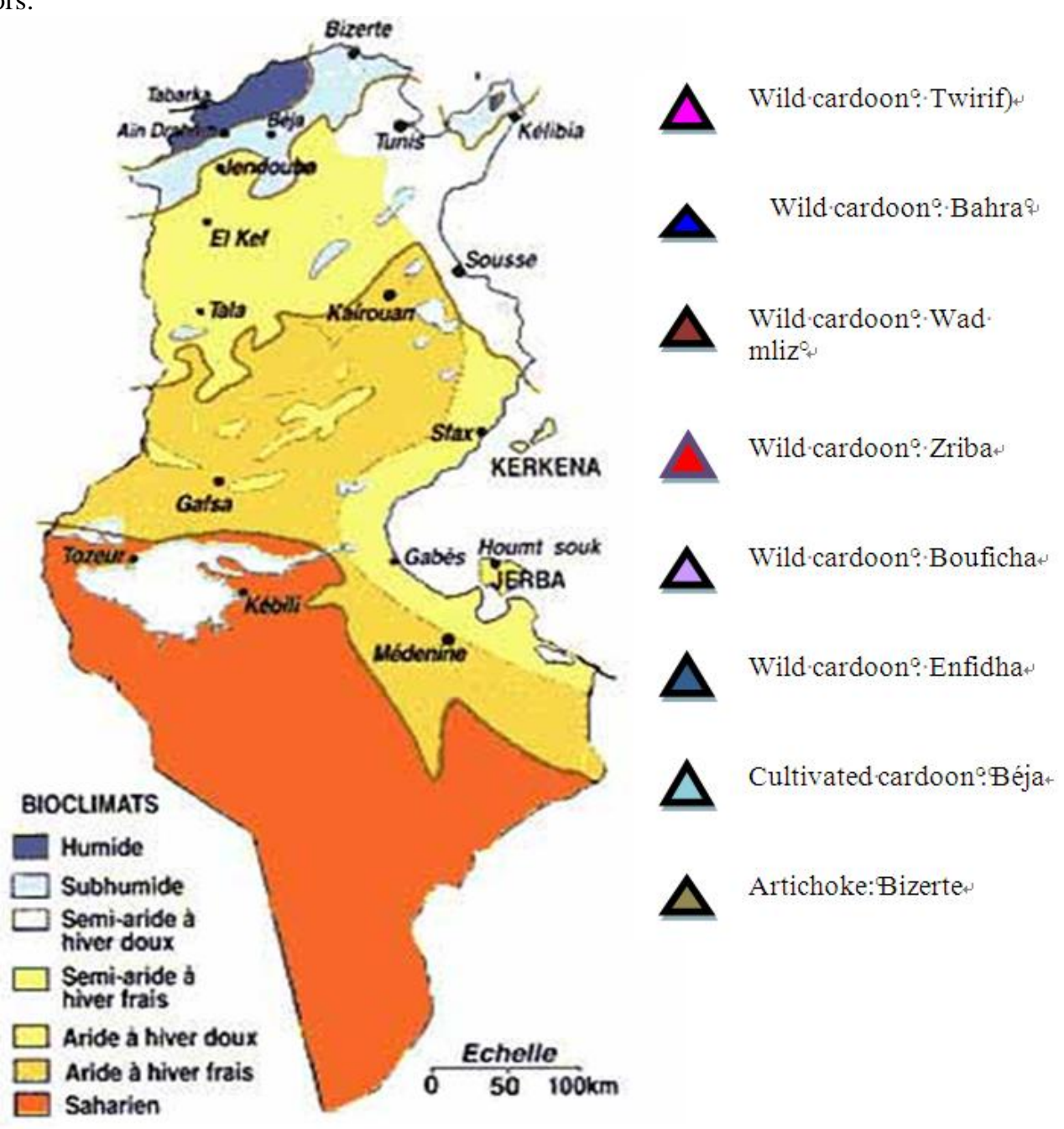

Figure 1. The geographical location of the studied populations of Cynara cardunculus $\mathrm{L}$

\subsection{Germination Conditions}

The seeds (25 per replication) were incubated in $9 \mathrm{~cm}$ Petri dishes on one Whatman paper \# 3 in four concentrations of $\mathrm{NaCl}(0 \mathrm{~g} / \mathrm{L}, 2 \mathrm{~g} / \mathrm{L}, 4 \mathrm{~g} / \mathrm{L}$ and $8 \mathrm{~g} / \mathrm{L})$. The Petri dishes were hermetically sealed with parafilm to prevent evaporation and then placed in an incubator in the dark at $25 \pm 1^{\circ} \mathrm{C}$.

Germination was determined at $24 \mathrm{~h}$ intervals until for two consecutive days no further seed germinated. The seeds were considered germinated when there was radicle protrusion through the seed coat. Germinated seeds were quickly removed from the Petri dishes every 3 days and
- Six populations of wild cardoon, one population of cultivated cardoon and one population of artichoke "Blanc Oranais".

- Four concentrations of $\mathrm{NaCl}: 0 \mathrm{~g} / \mathrm{L}, 2 \mathrm{~g} / \mathrm{L}, 4 \mathrm{~g} / \mathrm{L}$, and $8 \mathrm{~g} / \mathrm{L}$.

All populations were collected during summer 2011 in different localities of Northern Tunisia; their localisation is reported in Figure 1.

Heads were harvested on July 15, 2011, when the plants were completely dried up and the grain had a moisture content less than $6 \%$. The seeds used for the experiment were 11 months old and they were stored in plastic bottles at $20^{\circ} \mathrm{C}$. The salinity stress was obtained adding $\mathrm{NaCl}$ solution to the germination medium. 


\section{Results}

\subsection{Final Germination Percentage}

As regards the total germination percentage at $0 \mathrm{~g} / \mathrm{L}$, under no salt stress condition of germination, six populations on the studied eight ones showed values exceeding 60\%, and two of them reached $80 \%$ (Figure 2).

On average of all the studied concentrations of $\mathrm{NaCl}$, a good variability of germinability values under salinity stress was observed between the studied populations of Cynara cardunculus (Figure 2).

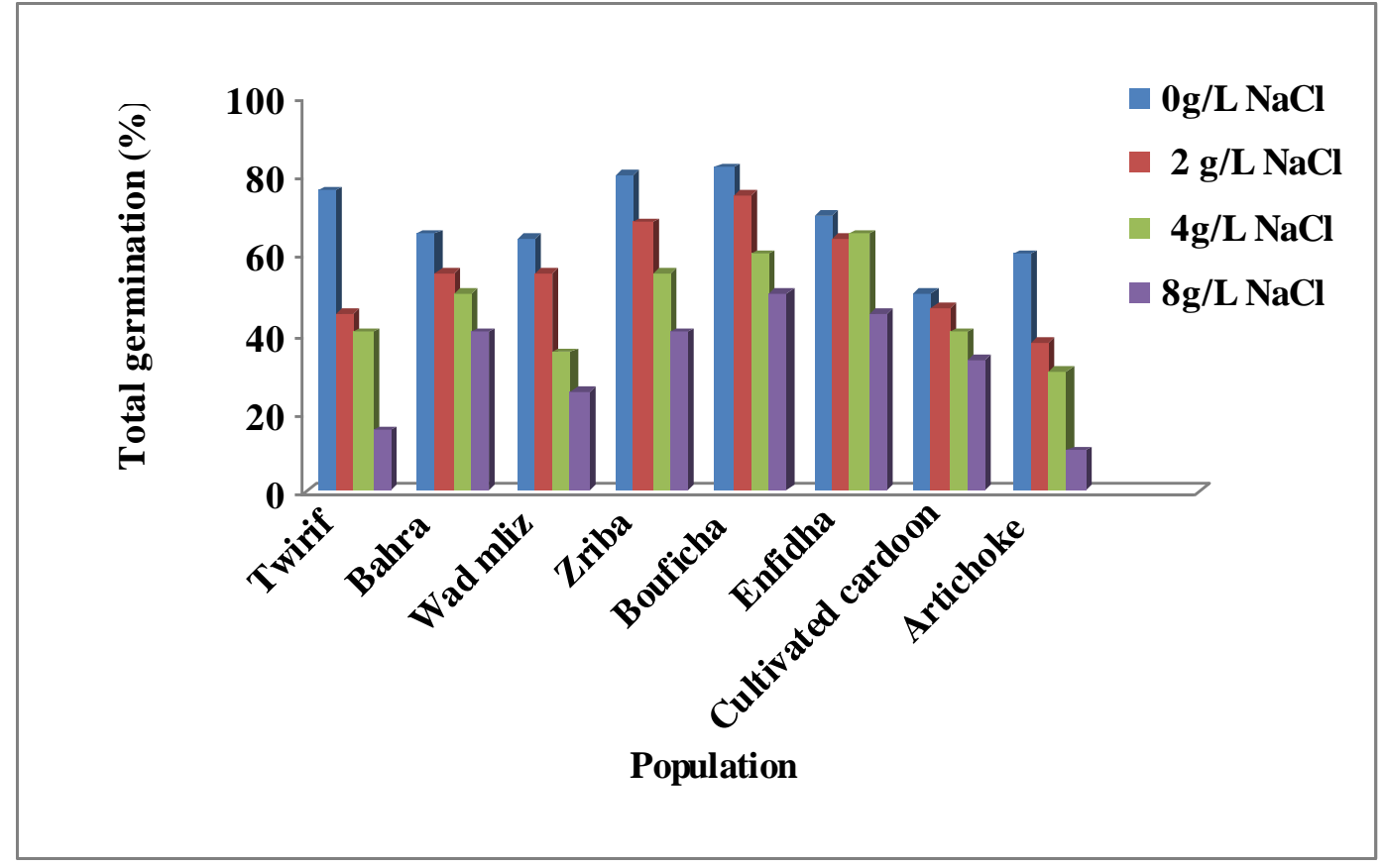

Figure 2. Variation in total germination (\%) of the studied populations of Cynara cardunculus L. according to different concentrations of NaCl

Among the studied populations, Zriba, Bouficha and Enfidha showed the highest germinability values under salinity stress at $2 \mathrm{~g} / \mathrm{L} \mathrm{NaCl}(68 \%, 75 \%, 64 \%$, respectively), at $4 \mathrm{~g} / \mathrm{L} \mathrm{NaCl}$ ( $55 \%, 60 \%, 65 \%$, respectively) and at $8 \mathrm{~g} / \mathrm{L} \mathrm{NaCl}$ ( 40\%, 50\%, 45\%, respectively).

Our results showed also that the cultivated cardoon and the artichoke have the lowest germinability values under no salinity stress at $0 \mathrm{~g} / \mathrm{L} \mathrm{NaCl}$ while, the artichoke showed the lowest germinability values under salinity stress at $2 \mathrm{~g} / \mathrm{L} \mathrm{NaCl}(37.5 \%)$, at $4 \mathrm{~g} / \mathrm{L} \mathrm{NaCl}(30 \%)$ and at $8 \mathrm{~g} / \mathrm{L} \mathrm{NaCl}(10 \%)$.

The ANOVA analyses (Table 1) show a highly significant variation between the eight cardoon populations for the germination percentage and between the four concentrations of $\mathrm{NaCl}$. This result shows a large variability of germination between the studied populations depending of the concentration of $\mathrm{NaCl}$ tested.

Table 1. ANOVA analyses of the two experimental factors (eight populations of cardoon and four concentrations of $\mathrm{NaCl}$ ) using the PAST program

\begin{tabular}{|c|c|c|c|c|c|}
\hline & $\begin{array}{c}\text { Sums of } \\
\text { squares }\end{array}$ & df & $\begin{array}{c}\text { Mean of } \\
\text { squares }\end{array}$ & F & Pr $>$ F \\
\hline Population & 14144,4 & 31 & 456,269 & 11,1042 & $\begin{array}{c}< \\
0,0001 \\
\text { HS }\end{array}$ \\
\hline $\begin{array}{c}\mathrm{NaCl} \\
\text { concentration }\end{array}$ & 22109,8 & 3 & 7369,93 & 179,362 & $\begin{array}{c}< \\
0,0001 \\
\text { HS }\end{array}$ \\
\hline Error & 3821,34 & 93 & 41,0897 & & \\
\hline Total & 40075,5 & 127 & & & \\
\hline
\end{tabular}

HS: Variation highly significant at $\mathrm{p}<0.05$.

\section{Discussion}

The obtained results showed a good variability among Cynara cardunculus populations in salinity resistance during germination. In fact, the artichoke seems the most sensitive to salinity stress than the cultivated and wild cardoon. [3] showed a good variability among wild cardoon populations both in salinity resistance and water stress during germination.

Our results showed also that the wild cardoon is more resistant to salinity than the cultivated one and had the highest germinability values under no salinity stress at $0 \mathrm{~g} / \mathrm{L} \mathrm{NaCl}$. In addition, Zriba, Bouficha and Enfidha showed the highest germinability values under salinity stress at $2 \mathrm{~g} / \mathrm{L} \mathrm{NaCl}, 4 \mathrm{~g} / \mathrm{L} \mathrm{NaCl}$ and $8 \mathrm{~g} / \mathrm{L} \mathrm{NaCl}$ and the artichoke shows the lowest value of germination at $8 \mathrm{~g} / \mathrm{L}$ $\mathrm{NaCl}$.

Moreover, [16] indicated that Cynara cardunculus could be considered as a facultative halophyte (plants that occur on slightly saline soils but which growth is soon inhibited when the salt level rises) and showed that the high production of epigeal biomass by this plant, a character that is not present in halophytes suggests the possible utilization of Cynara cardunculus in the phytoremediation programs of saline soils.

\section{Conclusion}

The obtained results showed that the studied populations of wild cardoon are more resistant to salinity stress than the cultivated cardoon and the artichoke and can be useful to select lines suitable to the cultivation in arid and semi-arid regions of Tunisia, where frequently saline stress conditions are presented in soils. 


\section{References}

[1] Rottenberg, A; Zohary, D, The wild ancestry of the cultivated artichoke. Genetic Resources and Crop Evolution 43, 53-58, 1996.

[2] Portis, E; Acquadro, A; Comino, C; Mauromicale, G; Saba, E; Lanteri, S, Genetic structure of island populations of wild cardoon (Cynara cardunculus L. var. sylvestris [Lamk] Fiori) detected by AFLPs and SSRs. Plant Sci, 169, 199-210, 2005.

[3] Raccuia, SA; Mainolfi, A; Mandolino, G and Melilli, MG, Genetic diversity in Cynara cardunculus revealed by AFLP markers: comparison between cultivars and wild types from Sicily. Plant Breeding, 123, 280-284, 2004.

[4] Dridi, B. Un systéme intégré de micropropagation de l'artichaut (Cynara scolymus L.), thesis submitted to obtain the degree of Doctor (Ph.D) in Agricultural Sciences and Applied Biological, 2003. University of Gent, pp. 22.

[5] FAO, 2002: Yearbook. FAO, Rome.

[6] Messmer, M; Schneider, E; Stekly, G and Buter, B, Determination of the progenitors and genetic stability of the artichoke cultivar "saluschocke" using molecular markers. J Herbs Spices Med Plants, 9, 177-182, 2002.

[7] Martino, V; Caffini, N; Philippson, J.D; Lappa, A; Tchernitchin, A; Ferrar, G, Identification and characterization of antimicrobial components in leaf extracts of globe artichoke (Cynara scolymus L.), Acta Hortic, 501,111-114, 1999.

[8] Fratianni, F; Tucci, M; De Palma, M; Pepe, R and Nazzaro, F, Polyphenolic composition in different parts of some cultivars of globe artichoke (Cynara cardunculus L. var. scolymus (L.) Fiori), Food Chem, 104, 1282-1286, 2007.

[9] Krizková, L; Mucaji, P; Nagy, M; Krajcovic, J, Triterpenoid cynarasaponins from Cynara cardunculus L. reduce chemically induced mutagenesis in vitro, Phytomedicine, 11, 673-678, 2004.

[10] Slanina, J., Taborska, E., Bochorakowa, H., Humpa, O., Robinson, W.E., \& Schram, K.H, New and facile method of preparation of the anti-HIV agent 1, 3-dicaffeoylquinic acid, Tetrahedron Letters, 42, 3383-3385, 2001.

[11] Qureshi, M.I; Israr, M; Abdin, M.Z and Iqbal, M, Responses of Artemisia annua L. to lead and salt-induced oxidative stress. Environ. Exp. Bot, 53, 185-193, 2005.

[12] Koca, H., Bor, M; Ozdemir, F and Turkan, I, The effect of salt stress on lipid peroxidation,antioxidative enzymes and proline content of sesame cultivars, Environ. Exp. Bot, 60, 344-351, 2007.

[13] Inan, G., Zhang, Q; Li, P; et al. Salt Cress, a Halophyte and Cryophyte Arabidopsis Relative Model System and Its Applicability to Molecular Genetic Analyses of Growth and Development of Extremophiles, Plant Physiol, 135 (3), 1718-1737, 2004.

[14] Arslan Ashraf, M; Ashraf, M and Ali, Q, Response of two genetically diverse wheat cultivars to salt stress at different growth stages: leaf lipid peroxidation and phenolic contents, Pak. J. Bot, 42(1), 559-565, 2010.

[15] Larcher, W, Physiological Plant Ecology. Springer, Berlin, p 506, 1995.

[16] Gonzalez, B; Fournier, M; Ramos, J.M; and Benlloch, M, Strategies underlying salt tolerance in halophytes are present in Cynara cardunculus, Plant Science, 168, 653-659, 2005. 